\title{
János Kornai (1928-2021): One of the Intellectual Giants of the Twentieth Century
}

\author{
Gérard Roland ${ }^{1}$
}

Accepted: 24 October 2021 / Published online: 10 November 2021

(c) Association for Comparative Economic Studies 2021

The famous Hungarian economist János Kornai has left us. He was one of the most important intellectuals of the twentieth century. He suffered personally from both Nazism and communism, the two totalitarian regimes of the twentieth century.

Born in 1928 in an educated Budapest Jewish family, Kornai went to a German school and grew up bilingual as was the case with so many intellectuals in Central Europe at the time. His father, a lawyer who had represented the interest of German firms in Hungary started losing clients when Hitler came to power and was loaded on a train to Auschwitz. By the time, he was 16 in 1944, he had lost his father and his oldest brother and had barely escaped death himself (see his autobiography in Kornai, 2008). Only one in three Hungarian Jews survived World War II.

Given the trauma of the War and the crucial role played by the Soviet Union in defeating the Nazi regime, Kornai like many other members of the Jewish intelligentsia became a Communist. At the age of 19, he became a journalist for the central daily newspaper of the Communist party Szapad Nép. His world view was shattered when meeting in 1954 Sandor Haraszti who had been a respected party leader after World War II and had been arrested in 1950 as part of what came to be known the Rajk trials. (A Moscow-trial style Stalinist purge was organized in the early fifties in the satellite countries leading to the execution or imprisonment of various communist leaders.) The old man explained to Kornai how he had been tortured to confess to fabricated charges. Kornai was later dismissed from Szapad Nép with other journalists for having criticized the then Stalinist leadership and became a researcher at the Institute of Economics of the Hungarian Academy of Sciences in 1955.

Having worked as an economic journalist, he had gathered first-hand experience of how the planned economy really worked. His doctoral dissertation in economics, Overcentralization in Economic Administration (Kornai, 1959), was full of facts about the flaws of central planning and represented a great breath of fresh air in the intellectual atmosphere of the times. Despite having at the time no Western training in economics, the book displayed Kornai's acute sense of observation and his

Gérard Roland

groland@econ.berkeley.edu

1 University of California, Berkeley, Berkeley, CA 94720-3880, USA

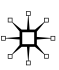


ability to formulate theoretical propositions by systematizing his observations. The thesis contained sharp observations about the incentive effects of plan indicators: the perverse effects of quantity indicators, the neglect of cost, bargaining for lower plan targets, the ratchet effect (avoidance of too large plan overfulfillment) shortage and irregularity of production and many of the typical characteristics of the planned economy. This was one of the first books to shed light on how the planned economy really worked, together with other pioneering work of the fifties by Granick, Berliner, Nove and Grossman. Even though the book did not draw conclusions about the system as such, it described in a fresh and critical way the reality of central planning and did not contain any Marxist jargon. As a rule, Marxists never wrote about the reality of central planning but engaged in Byzantine discussions on whether "the law of value" existed under socialism. To repeat, Marxists made ZERO contributions to our understanding of the reality of central planning.

The actual dissertation defense took place only one month before the revolution of 1956 and was a big intellectual event in Budapest. His defense was attended by a big crowd and was very much talked about. Given the visibility of his doctoral thesis, when the repression came, he lost his job at the Institute of Economics, was interrogated, and eventually got marginal jobs, first at the Light Industry Planning Bureau and later at the Textile Industry Research Institute.

Instead of becoming discouraged or cynical, he used the free time he had in these obscure jobs to study economics seriously and to get better acquainted with economic research that was being practiced in the West, on the other side of the Iron Curtain. Between 1958 and 1967, he studied by himself modern economics and educated himself in mathematical economics. He started working with a mathematician, Tamas Liptak, who helped him and with whom he did research on mathematical planning, a field that was then very active in the West. Their joint article "Twolevel Planning" (Kornai and Liptak, 1965) which provided a decomposition method for the solution of a planning model (the transformation of a large linear programming model into sub-problems with the center sending quantity signals and firms or sectors sending back shadow prices) was published in Econometrica in 1965 and became an instant hit in the economics profession. Kornai started getting invitations to give talks in the West and became quickly acquainted with the top economists of the time: Arrow, Hurwicz, Koopmans, Malinvaud and others. In a way, he benefited from the more liberal attitude of Hungarian authorities who let him travel, albeit at the cost of long bureaucratic procedures to receive permission to travel to the West. Scientists from many other socialist countries did not have that opportunity. As one could expect, in his travels to the West, he was usually spied upon by the Hungarian secret police. I have heard several times Hungarian intellectuals say Kornai was "lucky" to have been isolated by the regime because this left him time to become a famous academic. Needless to say, nearly all of those who were repressed did not become famous academics.

Instead of "just" becoming Central and Eastern Europe's top economist (together with the more senior Leonid Kantorovich, the inventor of linear programming, who received the Nobel prize in 1975), he wrote in 1971 a book with the provocative title Anti-Equilibrium (Kornai, 1971) that represented a thorough criticism of the relevance of general equilibrium theory, the crown jewel of economic theory. In the 
sixties, economic theory considered the market economy and central planning to be equivalent, at least seen through the prism of general equilibrium theory. This is at least the interpretation that one could make on the basis of the two welfare theorems of general equilibrium theory. Work on general equilibrium theory and on models of planning was quite close, often done by the same people. These were theories of perfect markets and of perfect planning, but Kornai was all too well aware that the reality of economic planning was very far away from the mathematical theory of planning. The most developed thesis of that book was that capitalist economies were in a state of constant excess supply (overproduction), whereas centrally planned economies were in a state of constant excess demand (shortage), and he drew out with minute detail all the implications of this analysis. The book also proposed to add considerations related to the informational sphere of the economy, developing themes such as informational asymmetries, bargaining, conventions, routines, aspirations - topics that would be developed later by other economists. I remember raising arguments from Kornai's book in my general equilibrium class in university, surely annoying the professor. Olivier Blanchard once told me he had a similar experience. Kornai's book was extremely popular among young rebellious economists who wanted to change the world.

In 1980, his magnum opus, Economics of Shortage (Kornai, 1980), came out. Whereas his earlier work on the economics of planning was mostly theoretical (all that the literature was very remote from how planning was done in reality), this was the first book to propose a systematic and powerful analysis of how the socialist economy really worked in practice. He developed there the concept of the soft budget constraint (state-owned enterprises in socialist economies that were making losses would never shut down) and took it as starting point of his analysis of the socialist system. The softening of budget constraints of firms tended to increase their demand for inputs, labor and capital. It also tended to make this demand insensitive to prices. As a result, resource constraints necessarily imposed themselves and this took the form of shortage. The book analyzes in great detail how economic agents (consumers and firms) adjust in the short term, medium term and long term to shortages. While performing this analysis, Kornai managed to deduce in a comprehensive way all the major phenomena that were associated with the socialist economy: bad quality, waste, lack of innovation, bad labor discipline, investment cycles, etc. He also explained the psychology of consumers, managers and workers having to live in such an economic environment and the choices they made in that environment. He used these micro-foundations to analyze how the different forms of adjustment to shortage in the economy contribute to avoid chaos and too large disequilibria. A simple glossing over the table of contents of the book shows how systematic and comprehensive his approach was. His presidential lecture for the econometric society (he was president of the Econometric society in 1978) published in Econometrica in 1979 gave a short overview of some of his analysis. Economics of Shortage had an enormous influence at the time. Those doing research on the socialist economy saw immediately that this was a very fundamental work. The analysis had very important repercussions on the thinking of economists living in Central and Eastern Europe but also in China. It certainly had an enormous influence on the reformers and the generation of economists who would be active in the transition from 
socialism to capitalism. The analysis was not only impressive by its comprehensiveness. It contributed strongly to the rejection among economists of partial reforms of the socialist economy. Reforms aiming at giving state enterprises more autonomy and introducing market mechanisms (so-called market socialism) would not change the system. Soft budget constraints would kill any form of market discipline.

No other book had analyzed the effects of shortages in such a comprehensive manner over hundreds of pages. His analysis was repeated in an even more comprehensive way in The Socialist System: The political economy of communism (Kornai, 1992), where he could write without resorting to self-censorship and explain clearly the role of the Communist Party in the institutional setup of the socialist economy.

When the Berlin Wall fell and communist regimes collapsed one after another in the late 1989, Kornai wrote a short book, The Road to a Free Economy (Kornai, 1990), outlining a clear program for an economic transition to the market economy. The title echoed Hayek's classic book Road to Serfdom. The book condemned any ideas to further reform socialism, even with simulated capital markets. There was no third road and only a transition to capitalism with private ownership as the main form of ownership would bring genuine economic change. The book also took a decisive position in favor of gradual privatization and against schemes of mass privatization. He emphasized the need for an organic development of the private sector and the gradual development of a middle class. He was very skeptical that socialist economies could be privatized by "cavalry attack." His views won the day in Hungary but not in Russia and Czechoslovakia. Mass privatization led to many scandals, a great concentration of wealth in the hands of oligarchs, little if any efficiency improvements, lack of legitimacy for private property and eventual forms of backlash as we unfortunately see everywhere in the region, including in Hungary. The few of us who advocated gradualism in transition and were critical of mass privatization felt quite isolated at the time. Reality, however, proved us right and the economics profession, initially more favorable to big bang proponents like Jeffrey Sachs and Andrei Shleifer, Kornai's colleagues then at Harvard, eventually realized the flaws of that approach. A few years later, a famous economist like Joseph Stiglitz, criticized very vocally the big bang approach to transition and echoed ideas that proponents of gradualism had expressed as early as 1989 .

Kornai continued writing influential papers about transition and reforms in his nineties, even as his health gradually deteriorated. He made a splash in 2019 by expressing his regrets about having advised the Chinese communist regime on economic reforms. The results of those reforms were to create a "Frankenstein"-that is, a very successful capitalist economy under a communist regime representing the most important threat to freedom in the world today, due to its growing strength and hegemonic ambitions.

Throughout the transition process, Kornai always insisted on his "lexicographic preferences": freedom, human rights and democracy come above economic growth and material welfare. After having lived through Nazism and communism, he was sad to see at the end of his life that democracy was being dismantled by the Orbán regime in Hungary.

Unlike many of my good friends, especially co-authors such as Yingyi Qian and Chenggang Xu, I was never his student, but his books had, and still have, a profound 
influence on my thinking as an economist. The first time I met him in person, I was a graduate student and he was president of the European Economic Association in 1987. Needless to say, I was very intimidated by him and it took me a lot of courage to approach him to talk about research.

I was lucky to spend a month in 1992 at Collegium Budapest, where we got to talk more about transition. When he retired from Harvard in 2002, he came with his wonderful wife Zsuzsa to see me at Berkeley in a "farewell tour" he was doing of American universities. We stayed in close contact and wrote an article together with Eric Maskin for the Journal of Economic Literature (Kornai et al., 2003) surveying the literature on the soft budget constraint.

In 1999, the Nobel Foundation had asked Olivier Blanchard and me to organize a Nobel symposium on the Economics of Transition. Kornai was of course the big hero of the day. Often, these symposia are seen as a preamble to a Nobel prize. It was not to be, even though Kornai's name floated around for decades as a possible laureate for the Nobel prize in economics for his work on the socialist economy.

I was glad to be able to see him many times in his apartment in Buda after that, overlooking the Danube and to eat together in Óbuda at Sipos, one of his favorite restaurants. He profoundly loved his country and had developed deep roots in Hungary. Even though his English was spotless, he always preferred writing his books and articles in Hungarian first. He made me discover Imre Kertész and other Hungarian writers who he admired. He is not with us any more, but he will continue to inspire me as well as many other researchers. A true intellectual hero!

\section{References}

Kornai, J. 1959. Overcentralization in economic administration: A critical analysis based on experience in Hungarian light industry. Oxford: Oxford University Press.

Kornai, J. 1971. Anti-equilibrium: On economic systems theory and the tasks of research. Amsterdam: North-Holland.

Kornai, J. 1980. Economics of shortage. Amsterdam: North-Holland.

Kornai, J. 1990. The road to a free economy: Shifting from a socialist system-the example of Hungary. New York: Norton.

Kornai, J. 1992. The socialist system: The political economy of communism. New York: Clarendon Press.

Kornai, J. 2008. By force of thought: Irregular memoirs of an intellectual journey. Cambridge: MIT Press.

Kornai, J., and T. Lipták. 1965. Two-level planning. Econometrica 33(1): 141-169.

Kornai, J., E. Maskin, and G. Roland. 2003. Understanding the soft budget constraint. Journal of Economic Literature 41: 1095-1136.

Publisher's Note Springer Nature remains neutral with regard to jurisdictional claims in published maps and institutional affiliations. 